\title{
MULTI-LAYERED COMMUNICATION AND FUNCTION \\ IN SCOTTISH TRAVELLER CANT
}

\author{
THOMAS A. MCKEAN
}

Scottish Traveller Cant, a secret cover language used for communication in small groups and families, has changed in both context and function over the last century. From being a cryptolect used entirely within the culture it has now received exposure through Traveller performance and publications. Throughout these developments, the Cant continues to be a way for Travellers to control the narrative of who they are and who they wish to be. Using songs, stories, and interactions with fieldworkers, this paper explores the power of language to define and shape identity.

Keywords: Traveller-Gypsy, Cant, Scotland, secret language, insider, self-determination
Škotski jezik popotnikov (cant), skrivni jezik, kise uporablja za komunikacijo v majhnih skupinah in družinah, se je $v$ zadnjem stoletju spremenil tako po kontekstu kakor po funkciji. Kerje bil kriptolekt, ki seje v celoti uporabljal samo $v$ eni kulturni skupini, je zdaj z odmevnostjo popotnikov (Travellers) in njihovih publikacij precej poudarjen. $\mathrm{Ob}$ teh spremembah ostaja način, kako popotniki nadzorujejo pripovedi o tem, kdo so in kdo želijo biti. Avtor z uporabo pesmi, zgodb in interakcij na terenu raziskuje moć jezika pri opredeljevanju in oblikovanju identitete.

Ključne besede: Popotniki, cant, Škotska, skrivni jezik, insajder, samodoločitev

For generations, Scottish Traveller-Gypsy ${ }^{1}$ families have used Cant, a cryptolect made up of words, inflection, tone, and gesture, drawing on Scots, English, Gaelic, and Romani vocabularies, as a means of communicating among themselves in speech and song. This paper explores changing attitudes to the Cant through the lens of working life, fieldwork interactions, writing, and songs. I explore its role within the community and its growing exposure in wider society as Travellers continue to be both part of and separate from mainstream society. I contend that knowledge and use of the Cant remains a powerful tool for many Travellers, even as its role has changed from a practical and essential tool for work and safety in daily life to a marker of cultural identity employed in speech, prose, and song to assert ownership over the culture and the stories that are told about it. The Cant serves as a vehicle for control and empowerment, to be employed when Travellers want, for their purposes and to say what they want about themselves.

To establish a context for the Cant's cultural role, a little background on Scottish Travellers is apropos. The term refers to historically semi-nomadic groups all across Scotland, sometimes described as Scotland's indigenous people (IHT) and their origin legends range from them being the descendants of itinerant or clan tinsmiths (Gentleman, Swift, 1971: 9; Robertson, 2003: 15m25s, 2005; Douglas, 2006: 1, 5, 7-11) to positing possible cultural

1 Traveller is the preferred term in Scotland; this hyphenation is sometimes used as a shorthand to define the group to outsiders in brief. 
and genetic relationships to the incoming Gypsies, or "Egyptians," as they were called, based on misunderstood origins (McCormick, 1907: 386-400; Fraser, 1995: 111-20). As Stanley Robertson (2005) suggests, however, "the best people to ask are the travelling people themselves." His article "Scottish Travelling People" covers these diverse origin legends, as well as Traveller practices, the Cant, religion, skills, and identity.

Beginnings aside, many contemporary Scottish Travellers embody a distinctive worldview that often challenges mainstream society's cultural "norms," particularly around ownership, settlement, and social structures. Partly due to this divergence, and partly because of the "Other"-ness constructed around them, Travellers have faced discrimination and social exclusion for centuries. ${ }^{2}$ In 2019, the Scottish government acknowledged ${ }^{3}$ that by all indicators, "Gypsy/Travellers are worse off than any other community in Scotland," with attitudes described by the Scottish Human Rights Commission in 2013 as, "the last bastion of respectable racism."

But even as recently as the 1990s, moving from place to place along established routes, Travellers were counted upon for seasonal harvest work, hawking, and dealing in secondhand goods and rags, in many ways our earliest recyclers. Traditionally involved in dealing in horses, many are now car and caravan dealers, traders in used goods and property, turning the skills of craftsmanship and hawking into substantial businesses in contemporary life. Since the 1950s, it has been recognised that many Traveller families have a remarkable treasure-trove of traditional song, story, music, customs, jokes, riddles, and craft traditions, along with powerful interpretive styles (see Munro, 1996; Cooke, 2007; Douglas, 2007; Hillers, 2007: 159-61). ${ }^{4}$ This has brought positive exposure to Traveller culture, through concerts, recordings, and books, and gone some way towards breaking down social prejudice for some people. While many Travellers are settled and part of mainstream society, others maintain a life on the road, in summer time, at least. And while many in both of these groups identify as Travellers, others seek to avoid any association due to endemic social prejudice. ${ }^{5}$

Historically and to an extent today, Traveller Cant has been used to communicate details about the business of hawking and the deal itself, or secret warnings and messages regarding safety. Since Travellers were historically outside the structures and records of mainstream society, they were much more vulnerable than settled folk, as can be seen in

2 See Ó hAodha, 2002, for a look at the Othering of Gypsies in the context of English scholarship.

3 Scottish Government. Introduction, Improving the Lives of Gypsy/Travellers: 2019-2021. Joint Action Plan by the Scottish Government and the Convention of Scottish Local Authorities (COSLA). https:// www.gov.scot/publications/improving-lives-scotlands-gypsy-travellers-2019-2021/pages/1.

4 In addition to these examinations of aspects of Traveller tradition, there are numerous recordings, dissertations, books, and articles on individual Traveller artists, such as Stanley Robertson, Lizzie Higgins, Jane Turriff, the Fetterangus Stewarts, Jeannie Robertson, Duncan Williamson, the Stewart family of Blairgowrie, and many others.

5 For more on contemporary Traveller lives, see Travellers' Times (http://www.travellerstimes.org.uk/) and its parent organization Families, Friends and Travellers (https://www.gypsy-traveller.org). 
the widespread development and transmission of "Burker" stories, bodysnatching tales involving the abduction of adults and children for medical purposes. ${ }^{6}$

The Cant represents a secretive world of information sharing specifically designed to exclude the "country hantle" (non-Traveller country folk), or even other Travellers at times, with its extreme contextuality and idiolectal use in family units. But this private cover tongue, formerly found entirely within and for the Traveller community, used for practical purposes, has recently become instrumentalized as a means of controlling the narrative around Traveller identity and distinctiveness. In some cases, its use exposes an uneasy gap between the private and public spheres (as in Traveller publications, or folklore fieldwork) and, in others, can lead to internecine division, as community members disagree on how public it should become.

Perhaps most importantly, running through all of the contemporary uses of Cant discussed here is its use in song and story to rehearse a hoped-for reality, for Travellers to narrate who they are and want to be by explicitly articulating it, thus wresting capability, control, and the right to define who they are, from an often unjust world. As W. F. H. Nicolaisen writes,

\begin{abstract}
Once narrated, the past, harnessable for present and future encounters, becomes part of an experience which at least partially enables us to face and cope with what is coming to us. Unnarrated pasts are not available to us except, perhaps as connectionless chronicles, and can therefore not become nodes of experience. (Nicolaisen, 1985: 231)
\end{abstract}

In telling stories of triumph over adversity - featuring Cant as a pseudo-magical helper available only to the Traveller family - Travellers retell an aspirational, life-affirming version of the past to rehearse a resilient future in a world in which Travellers, as Eilidh Whiteford says, all too often fall foul of the authorities, often with tragic consequences. ${ }^{7}$ Cant is only one tool available to the community, of course. As part of mainstream society, Travellers also have access to English, Scots, and sometimes Gaelic. Through the use of these other cultural shibboleths, Travellers "assert their Scottishness and, consequently, their right to be treated as normal citizens of the country in which they live" (MacColl, Seeger, 1986: xi).

6 "Burkers" are so called after the famous Edinburgh murderers William Burke and William Hare who supplied sixteen bodies to Robert Knox for his anatomical work in 1827-28. For more on Burke and Hare, see Dudley-Edwards, 2014; Rosner, 2010; McCracken-Flesher, 2012, and for more on bodysnatching in the context of nineteenth-century anatomy, see Macdonald, 2003. Travellers' fear is not unfounded, for even in the twentieth century, Traveller children were forcibly removed from their parents' homes, sometimes for little reason, and sent abroad as orphans, or forced to attend ghettoised schools. One of our own students was taken away from her parents in the 1960s, never knowing that she had a brother, or that her parents had tried to find her for many years. She never saw them again. Others were taken away and trafficked to Canada by Quarrier's Homes earlier in the twentieth century. Jess Smith (2015) writes about a "Tinker's School" at Aldour in the 1940s and 50s (my thanks to Leslie Drury, National Co-Coordinator for Learning and Development at Article 12 (http://www. article12.org/) for drawing this to my attention).

7 Personal communication, 24 May 2021. 
"Cant" is in some ways a relative term, used to name difference from the majority tongue. Hence, in Scotland it interacts with the Scots language (a member of the Germanic branch, and a cousin to English), with a range of hybridizations from Gaelic, Romany, Latin, French, Arabic, and English, while in Ireland it is built around Irish, a Celtic language (Kirk, Ó Baoill: 1). Many words are unique to the Traveller community, specific regions, or even to particular families (see Kirk, Falconer, 2002; Clement, 1981). Numerous Traveller writers include lists of these derived words (e.g., Whyte, 1979), whereas pioneering Traveller author Stanley Robertson, in his glossary, indicates which words are so-to-speak pure Cant and which are borrowings, an interesting, highly reflective and reflexive approach to his own use of it (Robertson, 1988, cf. 2005: 319-320 for summary of the tongue, its uses, and some key vocabulary).

But the Cant is more than a language - a lexis and associated syntactic rules - it is also an idea, a contextual communication system that exists in the very fact that it is alive, in its use and social function, in its connotations rather than its denotations, and its vocabulary made meaningful by context, gesture, tone of voice, and visual input, perhaps more heavily than most languages (MacColl, Seeger, 1986: 40). As Traveller author Betsy Whyte says, after herself suggesting that it is not a language in the conventional sense, it works differently:

One word could have many meanings and could carry the meaning of a whole sentence, depending on the situation and the tone of voice. In fact, a Traveller could appear to be having a normal conversation with a non-traveller - but in reality be giving a message, perhaps a warning, to any traveller listening. (Whyte, 1979: 178; the routine capitalization of Traveller is a relatively recent phenomenon)

Ewan MacColl and Peggy Seeger echo this sentiment, suggesting that "one word may have to carry an enormous variety of meanings [...], with many of them applied to a variety of objects of similar shapes" (MacColl, Seeger, 1986: 39-40).

With such a highly developed contextual usage structure, the actual words spoken are sometimes not so important. Rather the action and style of use gives meaning to whatever actual phonetic combinations are used (cf. MacColl, Seeger, 1986: 40). Pat Hutchison of Macduff notes the extent to which Cant exists beyond the aural:

A lot o folk ken ${ }^{8}$ words in the Cant, but the bit that abody's missing is it's in the delivery, it's how fast you can deliver it, and the actions. So, somebody that actually knows the Cant as their language, they can speak to one another without embarrassing anybody. But it's there, and you can just go for it, and it's all in the

8 Most contributors whose words are quoted in this article speak a mixture of Scots and English. I thus include a brief glossary of Scots words at the end of the article, along with Cant words that are unglossed in the main text. Words are spelled as in their original sources - both Scots and Cant have unfixed orthographies - and my own transcriptions conform to the Dictionaries of the Scots Languagel Dictionars o the Scots Leid. 
delivery and the action. Eye movements, hand movements, the lot, fits in. And I think that's the thing.

So, it's like, I suppose, we can read the hieroglyphs in Ancient Egyptian, but we dinna really ken fit's said, what were the actions. If you look at the folk that's alive now and rummle it back and we'll get an idea: well, maybe nae always, and I think Cant is one o those languages that people hae misconceptions aboot it. But also, it's always in the delivery. (Hutchison, 2017: 24m30s)

Thus, the Cant is a language that is recreated, in highly localized and family-specific ways, and in physical space, each time it is used.

Another fascinating feature is the Cant's reliance on linguistic proximity and opposition for meaning and function. Most languages are fairly self-contained, self-referential, and selfaffirming. Cant, however, in its secretive cover guise, is most often used in contiguity with another language and indeed aspects of it require that opposition in order to function and have meaning, as the late Sheila Stewart, well-known singer, storyteller, and author, notes:

Cant is not a fluent language. We have got to use [English] joining words like and and the and it and but and aa. It's not a fluent language. Although you use these words - the folk still doesnae understand what we are saying. It serves its purpose. (Stewart, 2002: 190)

Thus, even among insiders, Cant's status - language, dialect, argot, or patois - is up for debate. Some suggest that it is but a limited set of words highly dependent on individual, family and social contexts for meaning, a result of the key functions it fulfilled; as a Traveller man once told Linda Williamson, "If you couldn't eat it, drink it, smoke it or f-ck it, there wasn't a word for it!' ${ }^{\prime \prime}$ Other evidence, in contrast, would support the idea that it is more or less a language, at last as far as vocabulary is concerned. For example, Jess Smith recently shared with me a list of more than a thousand Cant words compiled by a relative in North America, a number not far off the vocabulary needed for basic day-to-day conversation in a language, and these are only the words found in their own Perthshire family tradition. ${ }^{10}$

Until very recently, Cant had very little exposure, as such, in mainstream society. Pretty much the only situation in which settled folk would encounter it would be in chance meetings on the doorstep as a Traveller came to the house to offer a service, such as tinsmithing, making clothes pegs or brooms, or gathering rags and bones for reprocessing. Even then, the chances of it being used were fairly small, as it was reserved for specific communication regarding a prospective deal - how to take advantage of certain situations to get what was wanted and needed. As Belle and Alec Stewart said, as reported by MacColl and Seeger, it

9 Personal communication 28 May 2021.

10 Attached to personal communication, 7 June 2021. 
was “for private conversation when they don't want any strangers to understand what they're saying" (MacColl, Seeger, 1986: 38). That said, in areas where Travellers were routinely welcomed as part of the rural economy, and their children part of the school system, many basic Cant words - gadgie, deek, yalla (man, look, egg) - have become part of the everyday speech of some non-Travellers, too, creating a topolect of sorts. ${ }^{11}$

Though books are now the most likely medium through which outsiders might encounter Traveller language, song has historically played a significant role. Since Travellers were well known in rural areas for their song and music traditions, what better medium in which to encode hidden messages? Many Cant songs thus consist of a verse or two reportedly improvised on the spur of the moment. "Fit Did He Fake Ye," from Stanley Robertson (Figure 1), a Traveller with deep roots in the North-East of Scotland, is typical:

Fit did he fake ye, the barrie gadgie?

Fecked me a baabie, tae buy ma slab,

Stall yer mangin, fake tae yer naggins,

For we love you, oh yes we do.

[What did the man give you, the nice man?

Gave me ha'penny to buy my food,

Stop talking and take anything you can get...]

(Robertson, 2006; Roud 32205)

Jeannie Robertson told Hamish Henderson that this song was composed spontaneously in the 1920s by Sandy MacLeod at MacIntyre's berry field in Blairgowrie, Perthshire, in response to repeated visits by a missionary (Robertson, 1962). Whether or not these songs were so created, the telling of such circumstances amuses, entertains, and reinforces the image of the resourceful and quick-thinking Traveller.

According to Elizabeth Stewart,

The Cant is also a good way tae pass information among the Travellers if ye're in company wi scaldies. Here's a wee example for ye, sung tae the same tune as Love it is Teasin.

Whit did she bring ye? A lousy curdie

The shaun aul manishy should hae bung ye twa

Oh stall yere mangin here fakes a feekie

Bing the lowdee and fake avree.

11 I am grateful to Eilidh Whiteford, raised in the Banff-Macduff area, for drawing this to my attention. 


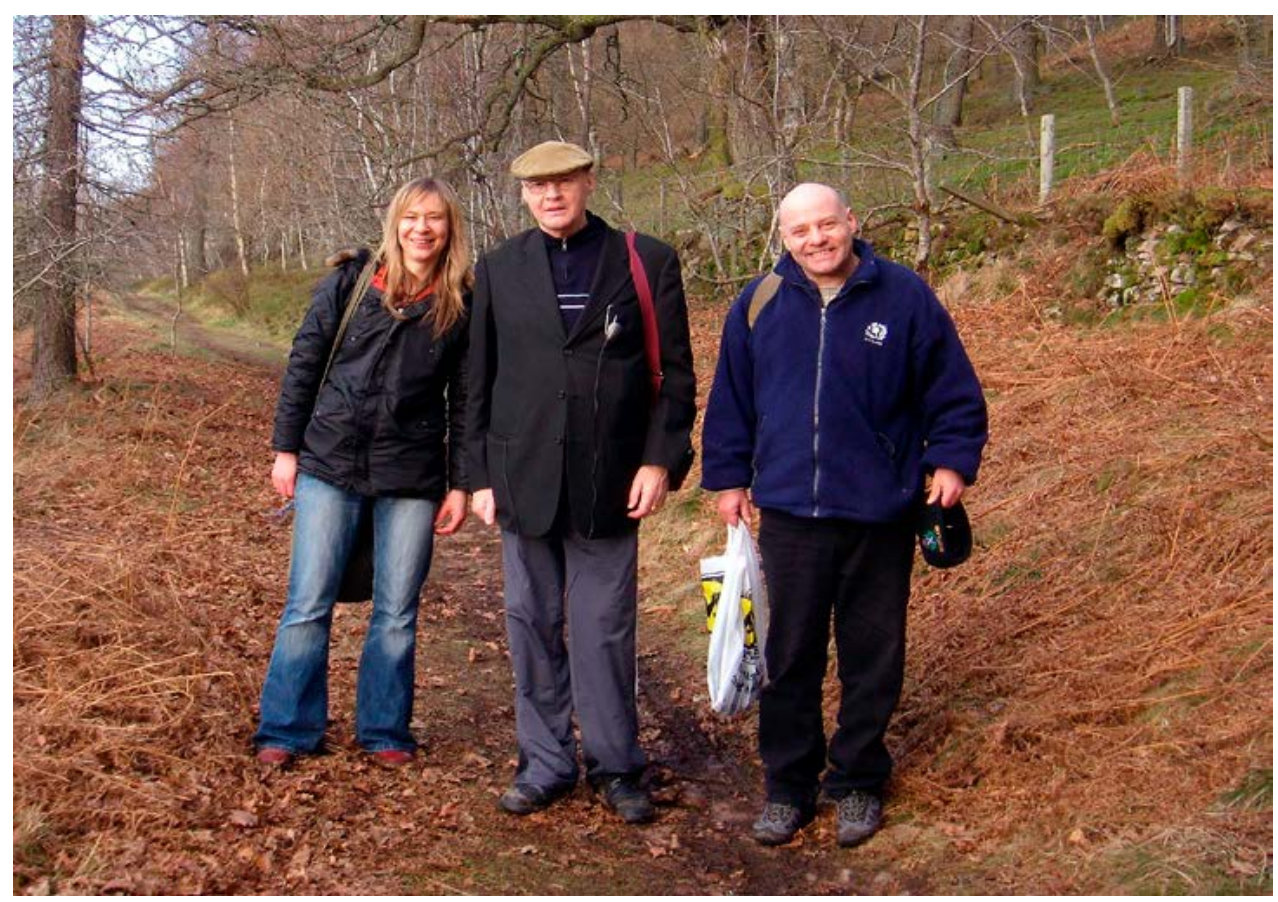

Figure 1. Stanley Robertson on the Old Road of Lumphanan, a traditional family refuge and camping site, with Sara Reith, Elphinstone Institute PhD researcher, and Steve Webb, Aberdeenshire, 2007 (photo by Martha Stewart).

Whit did she gie ye, a lousy curdie

The shaun aul manishy should hae gien ye twa

Watch whit ye're mangin here comes a hornie

Bing the lowdee an fake avree. [...]

Sometimes one word can have two different meanings, like fake could mean take or bring. Bing can also mean the same as fake, a lousy curdie is a greedy penny, feekie or hornie is a policeman, lowdee is money, an shaun is horrible. (Stewart, 2012: 253-254)

In this way, the assessment of a situation can be communicated easily between those in the know.

Tae me, it's a warnin language that keeps me an my family safe, an lets me communicate only wi my family an my kin. Say I wis amang non-Travellers (scaldie hantel), an some o my family were there, an I wanted tae warn them tae keep quiet. I might say, "stall ye mangin," or even jist, "stall.” Or I might even sing what I'm sayin, an my folks wid ken then tae keep quiet. (Stewart, 2012: 253) 
Such a warning system can even work in the face of a supernatural threat, as seen in Duncan Williamson's story, “The Elf and the Basket Maker," where a Traveller man warns his wife of the presence of a potentially malevolent creature who has returned to camp with him, "Mary, can ye deek the wee gadgie?" (Mary, can you see the little man?; Niles, Forthcoming).

But the Cant can also be used in everyday high-stakes situations, as Betsy Whyte notes, saying it was "very useful" and "could be used very cunningly indeed" (Whyte, 1979: 178), and offering a visceral example in which she could warn her husband that someone in authority, like the "Assistance Man" (Benefits Inspector), was at the door:

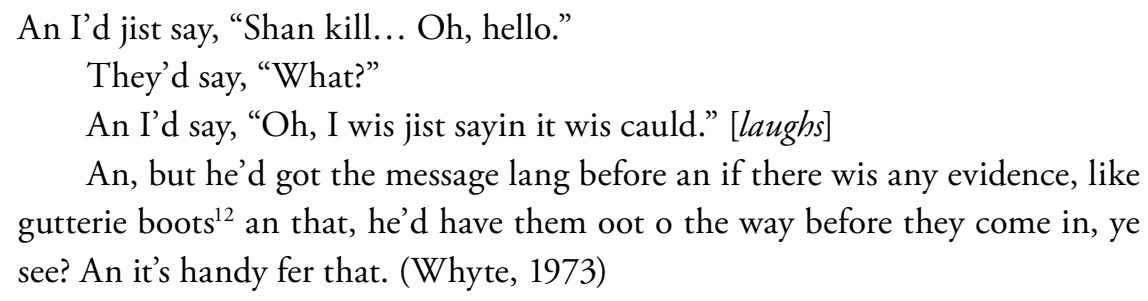

The arrival of a Benefits Inspector was certainly important, but almost trivial compared to a situation in which officers might be visiting not just to monitor work, income, and dog licensing, but, far worse, potentially to take children away from the family and into care. ${ }^{13}$ Thus, the children, and even the working dogs, were well versed in understanding warnings and keeping out of sight. Whyte's dog, Ricky, knew plenty of Cant, including words for illicit quarry, such as rabbits, and warnings commanding him to hide, as in the above anecdote (Whyte, 1990, chapter 2, and see 3-5 for more occasions when the dog knowing some Cant was important). The Cant had international applications, too, with several anecdotes about its use during World War II to keep secrets from the opposing forces. Lucy Stewart reports a POW in Germany eluding censors when writing home using Cant (Stewart, 1955), while several others tell of it being used to transmit sensitive strategic information (Whyte, 1979: 178; Edmondson, Ó Murchadha, 2002: 119).

On some occasions in a Traveller's door-to-door life, the Cant could be employed to save people from robbery, or worse. Many years ago, Elizabeth Stewart's grandmother sent her son, Ned (Elizabeth's uncle), and daughter to a house to drop off something the woman had purchased. The woman,

took them in tae pay them, an being quite a good-hearted aul woman, insisted that they should sit doon an hiv some dinner. Oh, but they didna want any dinner [...] Ye see, they saw that the woman wasna very clean, an the sight o the food

12 Rubber boots that might give away to the authorities that the man of the house had been poaching salmon, or pearl fishing in a local river.

13 Mike Doherty (2017), in the Travellers' Times, reports a recent worrying upturn in the number of Gypsy-Traveller children being taken into care. 
made them feel sick. Anyway, the woman locked the door so they wouldna leave withoot eatin. So they had nae way of gettin oot o it, but before they ate it, Ned said The Grace an this is what I've been told he said:

Oh dear Father. How can we ha this manishy's shan habbin. Shannas! Shannas! Will you please give us strength to ha this auld culloch's clatty habbin get oor lowdy and bing avree? Amen.

The Grace means: Oh dear Father in Heaven. How can we eat (ha) this woman's (manishy's) horrible (shan) food (habbin). Will you please give us the strength to eat this aul woman's (culloch's) dirty food, get our money, an take off. Amen. (Stewart, 2012: 256, formatting as in original)

Here, the contrast between the Traveller world and that of the settled folk is stark and the grace exists in a quantum state - speaking different meanings to the two worlds through a single performative moment, with one text and a single voice. The country hantle listen to the connotation: the structure, context, and intonations of a devoted prayer to the lord, while the two Travellers apprehend the denotation: a warning, cleverly hidden behind enjoyable wordplay and deception.

A very similar dynamic, carrying comparable messages about situational control through the use of Cant, is found in Stanley Robertson's family story of a Traveller going door to door in the time of the "Burkers," body-snatchers in league with anatomists for the supply of fresh corpses (see note 5). At risk of poisoning by the family, the man is warned by a young Traveller boy, serving as a bonded labourer in the home, through a Cant song:

So, he cuidna tell him fit wis happenin. So, he startit tae sing till him in "Romani;"14 he says,

Pipe how the hashie gavels,

Pipe how the hashie haas,

Shan collich, shan pottie,

Bing avree an fek awa.

Ha aa the hantle's habben,

Ha a the hantle's haa,

Fek the neddies tae yer naggin

But dinnae sloch the hantle's slab.

14 "Romani" is sometimes used as a synonym for the Cant, really just meaning "other". Cant does, of course, have elements of Romani in it. 
[Listen to what the woman's saying and watch what she's eating. Beware of the old woman and man. Get out and get away. Eat any and all of the food; take as much as ye like, but don't drink the tea.]

An the woman says, "Stop singin in that Gaelic! We're tired of that Gaelic. Stop singin that Gaelic sounds!" As far as they kent, they jist thought the laddie wis high-spirited an singin in Gaelic. Bit it wis enough tae warn this man; he took it. (Robertson, 1979, my transcription; see Robertson, 2006, track 46 for another version (p. 24 for the above translation); the song is Roud 20032)

This example serves a double purpose, showing how Cant could be used as a clever warning mechanism while also demonstrating solidarity among Travellers, as the wee servant boy's loyalty to his people eclipses that associated with his indentured role.

These two stories reveal a truism within storytelling in general, and perhaps in these Cant stories in particular. Through narrative we create the past we want and, as Nicolaisen (1985) suggests above, the future selves we wish to be. In telling these stories of outwitting and escaping the wiles of hostile outsiders, Travellers assert control, both of the incident portrayed and the narrative of identity itself. For those with no power or status in society, the Cant thus affords an opportunity to be fully in control, not just of the situation, but of the medium and the message. ${ }^{15}$

While the verses in these previous examples have been, to a degree, work songs, rhymes that perhaps originally arose as spontaneous communications during a doorstep negotiation, other songs using the Cant are occupational, narrating aspects of Traveller life, principally, taking advantage of an opportunity when one presents itself. This was the life of Scotland's Travellers for generations. Food and supplies were thin on the ground and you had to take your chance when you got it. Most of their subsistence was gained by foraging and trading - crafts for food, labour for food, collecting rags and bones and scrap metal and selling them on. This song, for example, from Cathie Higgins of Blairgowrie, speaks of the life of the camp and being on the road:

15 For an Irish example, see Oney Powers' 1932 story, "The Strange Adventure of the Storyteller with the Enchanted Man," in which the characters exchange information and warnings in Cant (Mac Gréine, 1932: 294-298; my thanks to Barbara Hillers for bringing this story to my attention). While anchored in family experience, these narratives have the feel of legends, tales whose key features and motifs might crop up anywhere that a group needs to tell positive stories about itself. In Traveller storytelling, their most common expression is in the Burker stories, expressions of vulnerability and precarity in relation to mainstream society, which often feature narrow escapes and warnings through the use of Cant. Every Traveller storyteller I have ever met has a repertoire of these stories, many associated with their own family history (see, for example, Douglas, 1987: 104-105; Stewart, 2012: 4; a search for "Burker" on Tobar an Dualchais yields nineteen examples). 
Hi, bara manishie, will ye bing wi me?

$H i$, bara gadgie, I dinnae jan your fee;

Will ye bing, will ye ja, will ye bing tae the wattle?

If ye dinnae get habben, ye'll get some peeve.

[Hi, bonnie lassie, will ye go with me?

$\mathrm{Hi}$, bonnie laddie, I dinnae ken your face,

Will ye come, will ye hurry, will ye come to the camp?

If you don't get food, you'll get some drink.]

(MacColl, Seeger, 1986: 281)

Probably the best known, and widest spread, of any Cant song is "Big Jimmy Drummond" (Roud 2506), which has received more exposure in traditional song circles than the strictly Traveller, work-related warning songs discussed above. Willie MacPhee's version, as sung to Sheila Douglas, talks in harsh terms about the realities of being a Traveller in Scotland.

My name it is big Jimmy Drummond:

My name I will never deny.

I will moolie the gannies in dozens

[slaughter the chickens]

For there'll be naebody there for tae tell.

$O$ last night I lay in the cauld granzie

An this night I lie in the cauld jail,

For my mort an my kinchens are scattered

An I dinna jan whaur they may be.

And if iver I dae bing a-chorin

I'm be sure for tae gang by masel:

I will moolie the gannies in dozens

And there'll be naebody there for tae tell. [barn]

[wife and children]

[know]

[go stealing]

[slaughter the chickens]

The song references stealing, an activity only indulged in in extremity, ${ }^{16}$ and, as the man lies in jail instead of sleeping in a barn, he laments not knowing where his wife and

16 Closely allied to stealing, yet qualitatively different, is poaching, a famous Scottish pastime whose definition is relative to one's ideas on the right to own. "Black-fishers, poachers, and smugglers are a sort of gentry that will not be much checked," wrote Walter Scott in Red Gauntlet (1824). For Travellers, and many other Scots I know, poaching is part of a longstanding relationship with the natural world, and a sporting opportunism in the face of overreaching authority, that perhaps pre-dates some of our modern ideas of ownership, especially those developed by and for rich landowners, who, over the last few centuries, have taken possession by fiat and entitlement of lands traditionally judged to be, in effect, common property, e.g., common grazings, common woodlands. For details on the politics of 
children are. It is significant that these two elements of the song are in Cant, fundamental as they are to the Traveller experience. First, the struggle to find enough food for the family and second, the Travellers' vulnerability to the authorities, whether through arrest or the dispersal of the family itself (see note 4). By using Cant in these key moments of the song, the Traveller protagonist controls the narrative arc of, and audience for, the song, speaking directly to his compatriots of what it is to be a Traveller, to be at the mercy of both the environment and of the civil authorities.

According to Duncan Williamson, this song is based on a real man with whom his brother, Jock, stayed on Arran. And, he says, Drummond was something of a Robin Hood figure who,

couldnae stand to see any child hungry. If the Travellers had no meat for their kids, Jimmy Drummond would go an he would steal hens, and he would steal onything. He'd steal fish at the rivers; he was a great salmon poacher. And he was a kind of Traveller Robin Hood among the Travellers. And if it was his last penny he had in his pocket, he would give it to you. That's the truth, because Jock sat here and told me the story. (Niles, Forthcoming)

There's "not much tae 'Jimmy Drummond,' according to Duncan Williamson, but this deceptively simple song actually encapsulates some deeply significant aspects of Scottish Traveller culture, reminding Elizabeth Stewart that she comes "fae very special people an that we have oor ain traditions tae be proud o" (Stewart, 2012: 254). Existing as they have on, and at times beyond, the outskirts of society, Travellers have always had to negotiate their presence, at times pushing the boundaries of legality (a-chorin) to survive. From a Traveller perspective, an indigenous people with a pre-enclosure relationship to ownership and possession, ${ }^{17}$ taking food where you can get it is the right and only thing to do, a hunter-gatherer mentality in a click and collect modernity. And here, too, are the harsh realities of living on the margins: Drummond lies in jail, separated from his wife and children; perhaps they have been detained, or, at the very least, driven away by the authorities.

One pervasive aspect of the songs that we have looked at is a macaronic structure. Many macaronic songs move fluidly between languages, while others insert the lesser-used language for comic effect, often in an incidental, affectionate way, as in "Cumarashindu" ("The Coat of Blue", or "The Russian Jew," Roud 13562), in which an imitative Gaelic phrase is used as an epithet for a wise and benevolent Highland policeman. In some, macaronic insertions are used by those in high-status positions to make fun of those in

Scottish land ownership, see Mcewen, 1981; Cramb, 2000; Wightman, 2015; and for an example of a community that has taken matters into its own hands and reasserted its rights to common lands, see Callander, 2000.

17 See Bryden, Geisler, 2007, for a look at Scottish land reform movements in the face of centuries of feudal acquisition. 
the lower echelons by parodying their language in simplistic ways, undermining the entire cultural validity of the overshadowed language, while in others, speakers of the lower status language use it to push back against a hegemonic culture.

The macaronic context for Scottish Traveller Cant is quite different. Being a cryptolect, essentially a secret unknown to outsiders, Cant cannot be used in quite this way. In folk song, its use ranges from the entertainment of clever wordplay in mouth music, ${ }^{18}$ a practically non-sensical use for rhythmic and melodic diversion, to poignant songs like "Big Jimmy Drummond," in which the use of Cant pointedly highlights the "otherness" of the Travellers' world in relation to that of settled society. Thus, the Traveller singer speaks directly to his or her audience through an insider communication embedded within an outward-facing performance, saying what she wants about her own people to her own people.

Elizabeth Stewart uses Cant in her own compositions in similar ways, deliberately using it as a marker of identity, employed to retain control of the narrative. In "The Jolly Tinker," for example, she takes on Traveller identity and presents it in her own terms, simultaneously playing skilfully on outsiders' romantic notions of Traveller allure and exoticism. The song does its own romanticizing of Traveller life and culture, to be sure, a perspective that derives from the fact that many aspects - particularly travelling, moving, being on the road - are themselves receding out of the reach of present day experience, leading to a kind of nostalgia and a certain idealized view of the past.

\section{He deekit the manishy up an doon \\ For a barry culloch wis she \\ [Tae] fake her intae kip tae ma naggins \\ Bing the lowie and fake avree. *}

${ }^{*}$ He lookit the woman up and doon

For a good-lookin woman wis she

Tae get her intae bed tae masel

Get the money and gang awa.

(Stewart, 2012: 298-300, translation as in original)

In this anecdote, Stewart uses Cant to take charge of Traveller stereotypes, drawing on the most positive aspects to paint a picture of a confident, appealing, even magical individual. It is idealized in many ways, but it comes from within the culture, with Stewart in command, rather than at the descriptive mercy of an outsider in a position of status, power, and wealth.

18 Mouth music is a collective term for the singing of syllables set to dance tunes (jigs, reels, etc.); subsets include diddling, lilting, chin music, jigging, Scottish Gaelic puirt-à-beul, Irish Gaelic portaireacht bhéil. The words range from linguistically meaningless vocables to lyrics that, while making grammatical sense, are of little narrative import. See Kopka, 1997, for examples from different "Celtic" cultures and Sparling, 2014, for a study of Gaelic puirt-à-beul. 
Historically, in language encounter geographies and politics, the hegemonic culture uses the disempowered language (or the language they wish to disempower) in parodic ways, to make fun of, and thereby undermine the significance of, the entire culture. But because the Cant is essentially unknown to the outside world, wider society does not have that tool of oppression at its disposal. And here in Elizabeth's song, we instead see the Cant used from within to control the narrative, not just of the song, but of her culture.

Not only does the song paint a picture for the outsider listener of the Traveller in control of the seduction at the centre of the song (buying into the romantic view of the appealing, exotic Other), but within the song, the main character is able to use the Cant to communicate with fellow Traveller listeners, while simultaneously using it in the traditional role of facilitating business.

We have seen a number of different contexts in which the Cant is used in Traveller life and art, but it is now time to look at how this code system has become more widely known over the last fifty years or so. With the founding of the School of Scottish Studies in 1951, Travellers were soon "discovered" to be a rich source of traditional music, song, and story. ${ }^{19}$ The culture acquired a status in wider society (or at least in the world of folk music, traditional culture, and the traditional arts) and thus far more exposure, from local concerts to national radio coverage on the BBC. The society began to open up, to an extent, and outsiders learned far more about it than over many previous centuries during which it had essentially been a closed book, with a few forays by the curious, the academic, or - unhelpfully - the desperately romantic.

With this rapidly arriving exposure came questions and, sometimes, discomfort and debate. Should the culture be shared? Should the Cant be shared? If so, who has the right to share it? Who puts themselves forward and do they have a right to do so? Who should be the gatekeeper(s)? Whose Cant is the "right" one? From the early days of fieldwork, some Travellers were uncomfortable with opening up in this way, chary of sharing the culture and its internal intricacies with outsiders. Differing attitudes sometimes led to strife between and within families, as well as a feeling that some were exploiting their Traveller heritage, and accusations that some of these people did not have the "true" traditions. Stanley Robertson told me that when his Exodus to Alford came out in 1988, he was the brunt of some strongly negative comments from within Traveller culture.

I found an early insight into this discomfort around disclosure in a recording made by Hamish Henderson with the wonderful Lucy Stewart (Figure 2), of Fetterangus, Aberdeenshire, in 1955.

19 Hamish Henderson's oft-recounted story of his first encounter with Jeannie Robertson is the stuff of legend, redolent with motifs of the questing (male) folklorist and the (female) singer manqué, waiting to be discovered. It is recounted in Niles, 1986: 84-85, and see Kodish, 1987, for an illuminating antidote. For details about many aspects of Traveller oral performance traditions, see Beech et al., 2007, passim. 


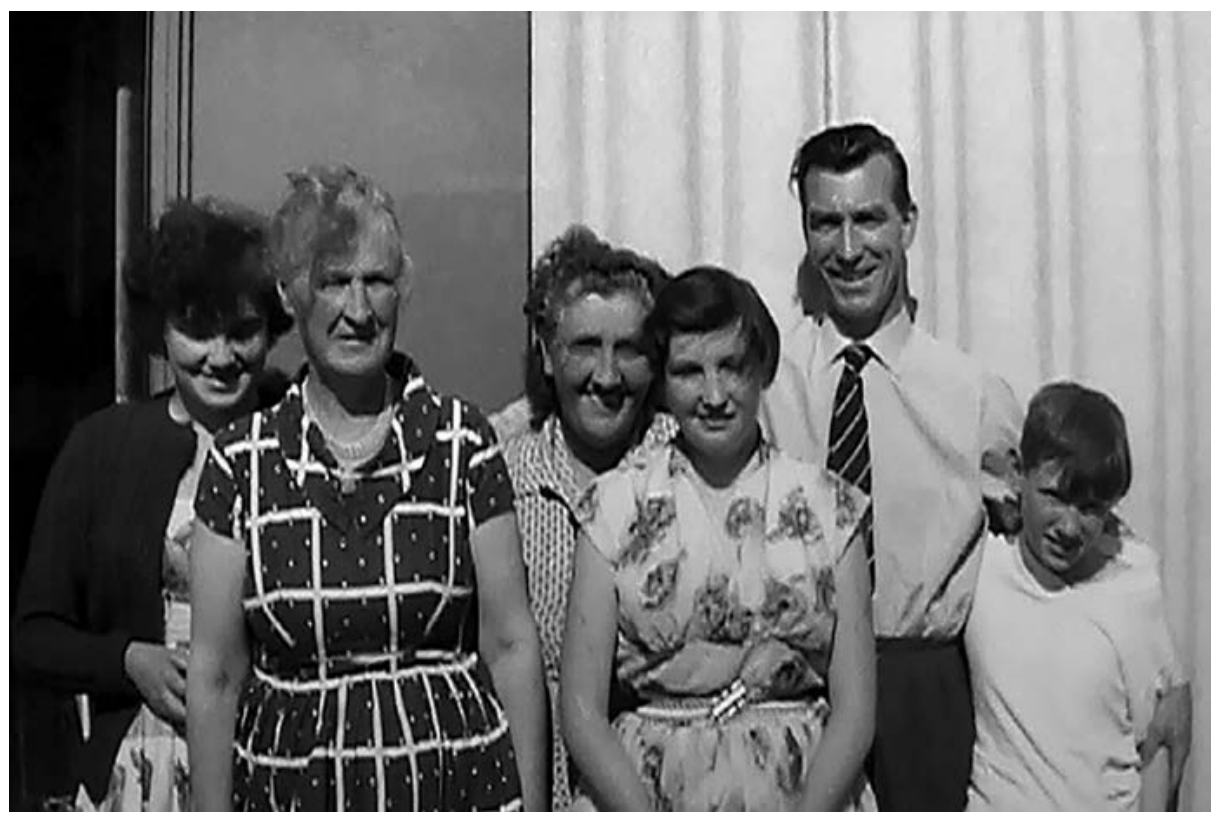

Figure 2. Elizabeth, Lucy, Jean, Frances, Ned, and Robert Stewart, Fetterangus, Aberdeenshire, 1959-60 (photo by Kenneth S. Goldstein).

LS: Hear this man?

$\mathrm{HH}$ : That's a barra...

LS: Ye hear him? Fit did ye say?

$\mathrm{HH}$ : I'm sayin it's a barra song that.

LS: A barrysong

$\mathrm{HH}$ It's a barry chaavie singin it tae. [laughter] [...]

LS: $\quad$ Fit aboot $a$-chorin? Fit's that? Say it again.

$\mathrm{HH}$ : Did ye iver get a song aboot, I'll gang, I'll bing nae mair a-chorin? [laughter] Did ye iver hear that?

Here, Hamish brings Lucy's niece, Elizabeth Stewart, into the conversation.

\section{LS: Bing nae mair a-chorin?}

$\mathrm{HH}$ : Did ye iver get a song like that? No?

ES: Aye.

LS: Fit's chorin, Elizabeth?

ES: Stealin.

$\mathrm{HH}$ : It wis anither manishie learnt me it. She tellt me it fin she wis feedin her jougals. [laughter]

LS: He's an affa man this. Far did ye pick up this man? 
Those in the room sound a little cagey, I feel; this is their language not his and the listener might be forgiven for thinking that Henderson was the Traveller, as the Stewarts cede no ground.

$\mathrm{HH}$ What would the council be, or the lawyer? Fit's that? Div you ken that? His mouthpiece? ${ }^{20}$

LS Mun?

$\mathrm{HH} \quad \mathrm{Mhm}$. A something-cowl, isn't it?

LS The mun.

$\mathrm{HH} \mathrm{Oh}$, the mun. Is there no a word, something-cowl

LS Mun?

JS A barra coull [laughter]

$\mathrm{HH}$ Tell us, what aboot a minister. If a minister came round tae see him in clink, an wis givin him a lot o jaa, what wid the minister be?

LS Shan gadgie!

$\mathrm{HH}$ Aye a shan gadgie, but fit's the word for a minister? Div you ken?

LS No.

$\mathrm{HH}$ An tell us, what aboot a horse, fit's a horse?

LS Gry?

$\mathrm{HH}$ Aye. And what aboot a cat?

LS I niver heard o a cat. I heard o a jougal.

$\mathrm{HH}$ A jougal, that's a dog.

LS Yes.

$\mathrm{HH}$ Did you, were you able to speak the Cant properly?

LS Yes.

$\mathrm{HH}$ Really?

LS Yes.

HH Uh-huh. (Stewart, 1955)

Here Henderson appears to know more than they do, or so they let him think, using his deep knowledge to elicit more and better information. There is the possibility, too, that the Stewarts are using the kind of gestural Cant described by Pat Hutchison to respond to each other while Henderson is questioning them, so we cannot be sure of the tenor of the interaction. Nevertheless, in this exchange, Lucy Stewart does sometimes seem reluctant to share, only confirming his propositions rather than volunteering much new information

20 Linda Williamson suggests that most Travellers would not have much to do with lawyers or solicitors and would have no use for such words that have little or no bearing on their daily lives (personal communication, 28 May 2021). That said, an American man of Irish Traveller descent reports that "there was a word for everything [...] I don't care what it was: they had a word for it" (Edmondson, Ó Murchadha, 2002: 119). 
of her own. In doing so, she protects insider knowledge from outsider encroachment and retains control by leaving Henderson content in thinking that he has reached the limits of their knowledge. (I have been around fieldwork long enough to know that contributors sometimes withhold deeply personal, insider information, as is their perfect right, and that praise of a fieldworker's thorough knowledge can be a somewhat backhanded compliment.) That said, Henderson was beloved by Travellers and went out of his way to learn Cant and about the intricacies of Traveller culture, for which he was much lauded and appreciated in the community (see Robertson, 2005: 316), though I have heard tell of some frustration, as well, as he moved into other aspects of his life and work, latterly not so involved.

Overarching these facts is the undoubted power dynamic in the interaction. While Henderson was deeply appreciative of his relationships with Travellers, reverential about their remarkable traditions, and unlikely to consciously assert his status, he nevertheless was highly educated, ex-military, associated with a university, male, and tenaciously determined to get results, a combination which, I believe, leads to an unspoken hegemony exemplified in the slightly insistent tone that comes through towards the end of this extract.

The exchange, full of provocative and tempting challenges, is generally good-humoured, to be sure, but perhaps with a measure of politeness from the Stewarts, rather than fullon participation. The interaction makes me, albeit a twenty-first-century listener, a little uncomfortable, especially in light of stories I have heard expressing some resentment towards fieldworkers, and some feelings of exploitation (e.g., describing another fieldworker, "He jist aboot bled us dry," "He jist aboot bade wi us"). Henderson's work is, of course, of its time, and we might expect a slightly different approach today, although we all undoubtedly have our own shortcomings over which others will pore in future.

In this exchange, the Traveller community, empowered by the attention and high regard given to song, story, and musical traditions and related cultural practices, is slightly on the back foot. A secret language, generally employed in times of stress and harassment, is being exposed by outside forces. They are not in control, as when sharing explicitly performative, socially expected, and valorized traditions like ballads, songs, and stories, but rather at the will of an outsider. They react to hearing insider information that is already out of their control, not shared by them but by others. Now the fieldworker is in the stronger position and his contributors find themselves in a strangely subordinate role, one at odds with supposedly being the experts at the centre of attention, their secret language of power, control, and identity out of their hands. ${ }^{21}$

Soon after their "discovery," Travellers began to tell their own story, without the mediation of fieldworkers who, in line with age-old paradigms, often approached them as

21 This paradigm is foundational to the discipline. It is seen in many fieldwork encounters, and not only with the Traveller community with its obvious social power differential, but also with rural farming folk and the doctors, schoolmasters, and ministers collecting songs from them over the centuries. For a look at some of the impacts of class distinction in the context of "collecting" (itself a one-way archetype), see Bearman, 2000; Bold, 2003; Gregory, 2009; Knevett, Gammon, 2016; Roud, 2017. 
"tradition bearers", somewhat passive carriers of song and story with little or no creative agency, or indeed wider cultural expertise. ${ }^{22}$ It is fitting that this naturally decolonializing activity comes from within the culture itself, albeit sometimes with assistance from outsider facilitators who were in positions of sufficient power to bring the early projects to fruition.

One of the first Traveller forays into telling their side of the story was Betsy Whyte's The Yellow on the Broom, a beautiful, simultaneously gritty and rose-tinted memoire of Traveller life in the early twentieth century (Whyte, 1979). The book contains a glossary of Cant words, probably the first book by a Traveller to do so, and many more have followed (early studies of Gypsy culture, e.g., McCormick 1907, often contain listings of Cant words, though these are generally more heavily Romani influenced than Scottish Traveller language is). Whyte's glossary puts her heart on her sleeve, offering reflections about what it is and how it is used.

The use of Cant in a book aimed at mainstream society raised some eyebrows in the community, as seen with Stanley Robertson's book, but following Whyte's lead many others have contributed to a wide body of Traveller writing (Robertson, 1988; Smith, 2002; Pullar, 2019, to name a $\mathrm{few}^{23}$ ). Naturally, there is a range of opinions within the community, internal conflicts, and issues of gatekeeping, but that is a discussion for another time.

Cant's function has changed radically over the last century. Instances in which it is needed as a protective cover language against outsider violence are fewer, while the itinerant door-to-door hawking has virtually ceased. Thus, its use in the context of time-honoured Traveller professions may be thought to be a thing of the past. For Willie MacPhee, even as far back as 1962, it no longer retained its true function:

Oh aye it's still to the fore, although I never crack it much to anybody, even tae them [other travellers]. I just speak normal. I never speak in Cant tae nae itherI like people tae hear what I'm sayin an understand what I'm sayin. But I ken plenty o folk that has a bad habit o sayin o ony other folk, ken, country folk like you, an they're crackin tae them. Suppose it doesnae mean a thing, they start, "O shannas, shannas, deek that hantle binging [hell, look at those non-travellers coming], shannas, shannas," or "A shan gadgie [dangerous man] bingin, deek, shannas, shannas." (MacPhee, 1992: 84)

22 Early fieldwork is almost entirely focused on content, the "items" of folklore, rather than context, meaning, and function. Thus, the recordings of the 1950 s and 60 s largely feature song after song, riddle after riddle, with little or no discussion about how the songs were used, or fitted into the culture, or the role that riddle guessing played in a social interaction and we are left with a barrage of riddles and answers, bereft of the contextual game that surrounded them; see, for example, nearly any 1950 s song recordings on Tobar an Dualchais, or Kenneth S. Goldstein's 1959 riddle session with Lucy Stewart, Jean Stewart, and Charles Fiddes Reid (Stewart et al., 1959).

23 For a close study of Stanley Robertson specifically as an author, rather than as a singer, storyteller, or piper, see Yamasaki, Forthcoming. 
Not only has Cant had its day, but MacPhee feels that it is impolite to point out difference by using it with non-Travellers. Willie was one of the most gentlemanly people I have ever been privileged to meet and thus, for him, an a-contextual use of the Cant would be downright rude:

It's iggerant, that. "Oh there's somebody comin," wad be better. It's an iggernant way o daein. It was used like a code language, so that country folk wouldn't understand it, just something like Gaelic. It was used more when country folk were around. But when we were amongst ourselves, we never cracked it at aa. Naw, naw, naw, naw, naw, naw, naw. (MacPhee, 1992: 84-85)

In a brief editorial note to the Tocher article cited above, Sheila Douglas quietly takes to task those who romanticise and perhaps exaggerate the travelling life, both within the culture and outside it:

These are the words of a man who is still living the traveller life and is in touch with many of those who still do, most of whom have not been "discovered" by collectors and folklorists, and who have not acquired the habit of doing things to please them. (MacPhee, 1992: 85)

She implies that Travellers have seen what is wanted and are more than happy to provide it, and by extension, that folklorists shape what is given them both inadvertently and on purpose, a phenomenon undoubtedly true.

Today, though, the Cant still retains functionality, as Travellers continue to deal with cultural outsiders, whether when dealing or in general public settings where a little confidentiality is desired. For many, it serves as a badge of identity, directly connecting individuals and families back to a time when Travellers were Travellers (i.e., on the road, building camps, etc.), an idealized time when all is imagined to have been well in the Traveller world, demonstrating authenticity to audiences of every kind.

So, where does this leave us in relation to issues of ownership and belonging? Sometimes the use of Cant in public places and media is seen as a betrayal of Traveller identity. From within, there is conflict about gatekeeping, questions of ownership and policing that I mentioned before: whose is the Cant to give away? What right do you have to share it outside the culture? Who elected you as spokesperson? If you share it, outsiders know something intimate about the group, which, in effect, gives them power over it, or at the very least, disempowers the group as it no longer has absolute dominion over its own culture and is ceding control.

In her book, Elizabeth Stewart is explicit about this: "I hiv only said a few words here in my book, but I would niver teach the scaldies oor language. It's wrong tae dee that. The 
language should be kept very secretive" (Stewart, 2012: 256). Knowledge gained allows the outsider to assert control, as Hamish Henderson did in the interview with Lucy Stewart discussed earlier. There is no defence against this - the pandora's box is opened and cannot be closed. Thus, the criticism Stanley Robertson received after Exodus to Alford was not only about for sharing what some thought should be secret, but also for being seen to put himself forward as the representative (not that he claimed any kind of universal spokesmanship).

Some of this discomfort derives from the contextuality of the Cant, how much it is created and recreated whenever it is used. In this fluid context, vocabulary lists such as those which appear in most Traveller memoires are necessarily incomplete at best, probably misleading, and completely miss the essence of the language. MacColl and Seeger note that "each individual, from our experience with the Stewarts, adds their own mak'-ye-up words and onomatopoeic creations, which may then enter the larger pre-existing vocabulary" (MacColl, Seeger, 1986: 41), but this, to me, misses the point, or, rather, calls for a much wider understanding of what we mean by language. In its free-flowing, contextual creativity, Cant functions as a vehicle for situation-specific communication, whether or not it is formally a language according to our everyday definition of that word.

Many Travellers think explicitly about the connection between the Cant and their identity. ${ }^{24}$ In Traveller culture - albeit usually in conversation with outsider fieldworkers many Travellers articulate a love for the language and a high regard for both its function and it as cultural shibboleth, marker, and cultural inheritance. Belle Stewart, for example, says,

I'd never want to drop the Cant. Never! I've passed it on to all my family. [...] Mind ye, there's a gey lot o' snobbish Travellers. [...] If your father and mother and all your back generation had to live with it and lived well with it and was respected, why the hell should you no' keep it up?' I'm not the least bit ashamed o' bein' a Travelling person. Definitely not. And nane o' my faimly's ashamed! (MacColl, Seeger, 1986: 38-39)

Indeed, "The Stewarts' love for Cant is intense. It expresses their uniqueness as Traveller and helps them feel secure and proud as a community within a community" (MacColl, Seeger, 1986: 41). Elizabeth Stewart would agree and explicitly sees Cant as a badge of identity:

Alongside my love of music is my love o Cant, an dealin. Cant, the language o the Travellin people means sae much tae me, an I love tae speak it. I think really I couldna live withoot speakin it. [...] The music, the songs, the Cant an the dealin, an aa the Traveller ways. (Stewart, 2012: 253, 257)

${ }^{24}$ Language is central to everyone's identity, of course, but this fact is usually assumed and unremarked upon. In the case of multilingual speakers, there may be said to be multiple identities to some extent, as any speaker of several tongues can attest. 
While for some a badge of intense pride, for others the Cant is to be hidden, not as a prized cultural asset, but rather as a tell-tale, giveaway sign of Traveller identity in the face of a society strongly prejudiced against the culture. As Belle Stewart says, "They say, 'Terrible, the hantle jan who we are.' That means, 'The people'll know who we are, you should never speak like that" (MacColl, Seeger, 1986: 38).

Even now, with its quotidian use much reduced, the language is mainly considered a private and domestic aspect of culture, not really to be shared outside the extended family unit. As Jess Smith, author, singer, and storyteller, recently said to me, "Cant is a personal choice, spoken in the home or between those who understand it." 25 So, it is truly an insider language used for esoteric communication. And Jess, in her 2002 book Jessie's Journey, provides a "Glossary of Unfamiliar Words" rather than the list of "Traveller Cant and Scots words used in my story" that Betsy Whyte provided twenty-three years earlier, in 1979. So, for Jess, the personal, intra-cultural existence of the language is important, an emphasis perhaps shaped by the wide revelation of Traveller culture through the folk revival, and, more specifically, through the growth of Traveller writing in the years since Betsy Whyte's pioneering book.

But the Cant is also a marketable "difference" from settled society, a tool that can be used - as is the community's undoubted right - to highlight variance, to intrigue the outsider, and assert control over both situations and cultural transmission. The observer's paradox applies well here, especially so because of the Cant's contextuality. When shared outside its functional environment, it loses sense, power, and significance completely.

This cunning way of using the Cant is dying out rapidly. And there is no possible way of retaining it. It is quite impossible to teach to anyone: only by being brought up with it from infancy can it be properly learned. We can tell the words to anyone, but how to use them is something which will be lost once the travellers of this generation are gone. Even now only about 150 to 200 words remain. (Whyte, 1979: 178)

So, for Betsy Whyte, there is regret that it is no longer used, but also a quiet pride in the very fact that the knowledge of how to use Cant is being lost and is unteachable. You have to be born within; you are privileged, or you are not, and the boundaries of identity are not porous. This dichotomy is informed by Betsy's understanding of the underlying issues:

Only a few words are used by young people and children-and those few are almost as familiar to non-travellers. ${ }^{26}$ For now that children are integrated in

25 Personal communication, 24 September 2020.

${ }^{26}$ It is only relatively recently that the word has been capitalized as a matter of course, part of campaigns towards attitudinal change in respect and rights for the Traveller community. 
schools, and young people work side by side with non-travellers, some Cant words have been integrated too. But most of our young people are so pleased at being accepted, integrated, that they refuse to learn much Cant - and even angrily rebuke their parents for using it.

As you will understand, this is a constant source of frustration, disappointment and sadness to the older folk. They see their children and grandchildren - brought up in towns and almost the same as non-travellers - look blankly and stupidly when Cant is spoken, not understanding what it is being said. (Whyte, 1979: 178)

In folk song, the use of the language ranges from the entertainment of clever wordplay in mouth music, the practically nonsensical use for rhythmic and melodic diversion, to poignant macaronic songs like "Big Jimmy Drummond", in which the use of Cant pointedly highlights the "otherness" of the Traveller world in relation to that of settled folk. Thus, the Traveller singer speaks directly to his or her audience, a communication within a communication, while outwardly entertaining all.

In the end, Cant is more than a language. It is a reflection, both in content and structure, of the fluid marginality of much of Traveller culture. By using it in highly controlled contextual ways, people can create, govern, and manipulate a cultural space that is all their own, one simultaneously part of and separate from the non-Traveller world, a construct of practice, usage, and behaviour, aided and abetted by a rich, flexible tongue as adaptable as the people themselves.

\section{GLOSSARY}

$C .=$ Cant,$S c .=$ Scots. Scots language verbal nouns normally end in -in where the English equivalent ends in -ing; these have not been noted here.

\begin{tabular}{|c|c|}
\hline Abody $S_{c .,}$ everyone (lit. all bodies) & Couldna/couldnae $S c$., couldn't \\
\hline Aboot $S_{c .}$, about & Crack $S c$. , chat, talk \\
\hline Amang $S c$. , among & Daein $S_{c ., \text { doing }}$ \\
\hline Aul Sc., old & $\begin{array}{l}\text { Dealin } S_{c . \text {., dealin (e.g., in second hand goods, horses, }} \\
\text { scrap metal, etc. }\end{array}$ \\
\hline Bade $S_{c .,}$ lived & \\
\hline Barra/barry $C$., good & Deek $C$., see \\
\hline Bing $C$., go & Didna $S_{c .,}$ didn't \\
\hline Cauld $S c .$, cold & Dinna $S c$., don't \\
\hline Chaavie $C$., child, young person & Doesnae $S c$., doesn't \\
\hline Chorin $C$., stealing & Doon $S c$. , down \\
\hline Coul/cowl C., man & Faimly $S_{c \text {., family }}$ \\
\hline
\end{tabular}


Fit $S c$., what (North-East Scots)

Gadgie $C$., man

Gannies $C$., chickens

Gey $S c$., very or great

Granzie $C$., barn

Gry $C$., horse

Hae/Hiv $S c$, have

Iggerant $S c$., ignorant

Ither $S c$., other

Iver $S c$., ever

Jan $C$., understand, know

Jist $S_{c \text {., just }}$

Jougals $C$., $\operatorname{dogs}$

Ken $S c$. , know, understand

Kinchens $C$., children

Mair $S c .$, more

Manishie $C$., woman

Meat $S_{c .}$, food

Moolie $C$., murder, slaughter

Mort $C$., wife
Nae $S_{c .}$, not

Naebody $S_{c .}$, no one

Nane $S c$., none

Naw $S c$., no

Onything $S c$., anything

Oot $S c$, out

Rummle $S c$., rumble (roll back, in this case)

Scaldie/scaldie hantel/hantle $C$., country (non-Traveller) folk

Shan $C$., bad (adj.)

Shannas $C$., bad (expletive)

Tae $S c$, to

Wasna $S c$, wasn't

Wee $S c$., small, little

Whaur Sc., where

Wi $S c$., with

Wid $S c$., would

Withoot $S c$., without

Wouldna $S c$., wouldn't

\section{REFERENCES}

Bearman, Christopher J. 2000. Who Were the Folk?: The Demography of Cecil Sharp's Somerset Folk Singers. The Historical Journal 43 (3): 751-775. DOI: https://doi.org/10.1017/S0018246X99001338.

Beech, John et al., eds. 2007. Scottish Life and Society: Oral Literature and Performance Culture: Vol. 10 of A Compendium of Scottish Ethnology. Edinburgh, East Linton: John Donald and Tuckwell, European Ethnological Research Centre, National Museums of Scotland.

Bold, Valentina. 2003. Ballad Raids and Spoilt Songs: Collection as Colonization. In The Flowering Thorn: International Ballad Studies, ed. Thomas A. McKean, 353-362. Logan: Utah State University Press.

Bryden, John, Charles Geisler. 2007. Community-based Land Reform: Lessons from Scotland. Land Use Policy 24: 24-34. DOI: https://doi.org/10.1016/j.landusepol.2005.09.004

Callander, Robin. 2000. History in Birse. 4 Vols. Finzean: Birse Community Trust.

Clement, David. 1981. The Secret Language of the Scottish Travelling People. Frazer Linguistische Studien: Sprachliche Sonderformen 15: 17-25.

Cooke, Peter. 2007. The Music of Scottish Travellers. In Scottish Life and Society: Oral Literature and Performance Culture: Vol. 10 of A Compendium of Scottish Ethnology, eds. John Beech et al., 213-224. Edinburgh, East Linton: John Donald and Tuckwell, European Ethnological Research Centre, National Museums of Scotland. 
Cramb, Auslan. 2000. Who Owns Scotland Now?: The Use and Abuse of Private Land. Edinburgh: Mainstream.

Dictionaries of the Scots Language/Dictionars o the Scots Leid. http://www.dsl.ac.uk.

Doherty, Mike. 2017. Gypsy, Roma and Traveller Children in Care - A TT Investigation. July 21, 2017. https://www.travellerstimes.org.uk/features/gypsy-roma-and-traveller-children-care-tt-investigation.

Douglas, Sheila, ed. 1987. The Kingo the Black Art and Other Folk Tales. Aberdeen: Aberdeen University Press.

Douglas, Sheila. 2002. Travellers' Cant in Scotland. In Travellers and Their Language, eds. John M. Kirk and Dónall P. Ó Baoill, 125-138. Belfast: Cló Ollscoil na Banríona.

Douglas, Sheila. 2006. The Last of the Tinsmiths: The Life of Willie MacPhee. Edinburgh: Birlinn.

Douglas, Sheila. 2007. Narrative in Traveller Scotland. In Scottish Life and Society: Oral Literature and Performance Culture: Vol. 10 of A Compendium of Scottish Ethnology, eds. John Beech et al., 49-57. Edinburgh, East Linton: John Donald and Tuckwell, European Ethnological Research Centre, National Museums of Scotland.

Dudley-Edwards, Owen. 2014. Burke and Hare. Edinburgh: Birlinn.

Edmondson, Ricca, and Níall Ó Murchadha. 2002. Collecting the Cant. In Travellers and Their Language, eds. John M. Kirk and Dónall P. Ó Baoill, 111-124. Belfast: Cló Ollscoil na Banríona.

Fraser, Angus M. 1995. The Gypsies: The Peoples of Europe. Oxford: Blackwell.

Gentleman, Hugh, and Susan Swift. 1971. Scotland's Travelling People: Problems and Solutions: A Report of a Study of the Nature and Problems of a Minority Group within Scotland's Population, with Recommendations as to the Possible Solutions to These Problems, Carried Out by a Research Section of the Scottish Development Department in 1969. Edinburgh: HMSO.

Gregory, David. 2009. Fakesong in an Imagined Village?: A Critique of the Harker-Boyes Thesis. Canadian Folk Music/Musique folklorique canadienne 43 (3): 18-26.

Hillers, Barbara. 2007. Storytelling and the International Folktale in Scotland. In Scottish Life and Society: Oral Literature and Performance Culture: Vol. 10 of $A$ Compendium of Scottish Ethnology, eds. John Beech et al., 153-170. Edinburgh, East Linton: John Donald and Tuckwell, European Ethnological Research Centre, National Museums of Scotland.

Hutchison, Patrick. Interview by Eilidh Whiteford, Macduff, 25 October 2017, courtesy of Eilidh Whiteford.

IHT, Indigenous Highland Travellers Facebook Group. https://www.facebook.com/groups/1570906289883064/ about.

Kirk, John M. and Gavin Falconer. 2002. Scottish Cant Words. In Travellers and Their Language, eds. John M. Kirk and Dónall P. Ó Baoill, 132-137. Belfast: Cló Ollscoil na Banríona.

Kirk, John M., and Dónall P. Ó Baoill, eds. 2002. Travellers and their Language. Belfast: Cló Ollscoil na Banríona.

Knevett, Arthur, and Vic Gammon. 2016. English Folk Song Collectors and the Idea of the Peasant. Folk Music Journal 11 (1): 44-66. https://www.jstor.org/stable/44987588.

Kodish, Debora. 1987. Absent Gender, Silent Encounter. Journal of American Folklore 100 (398): 573-578. DOI: https://doi.org/10.2307/540914.

Kopka, Matthew, ed. 1997. Celtic Mouth Music. Port Washington: Ellipsis Arts, CD4070.

Mac Gréine, Pádraig. 1932. Further Notes on Tinkers' "Cant": Together with Some "Travellers" Tales, Customs, Beliefs and Prayers. Béaloideas 3 (3): 290-303. DOI: https://doi.org/10.2307/20521708.

MacColl, Ewan, and Peggy Seeger. 1986. Till Doomsday in the Afternoon: The Folklore of a Family of Scots Travellers, the Stewarts of Blairgowrie. Manchester: Manchester University Press. 
MacDonald, Helen. 2003. Legal Bodies: Dissecting Murderers at the Royal College of Surgeons, London, 1800-1832. Traffic: An Interdisciplinary Postgraduate Journal 2: 9-32. https://minerva-access. unimelb.edu.au/bitstream/handle/11343/34168/66604_00001777_01_Dissecting_Murderers. pdf?sequence $=1$.

MacPhee, Willie. 1992. Last of the Travelling Tinsmiths. Tocher 44: 78-90.

McCormick, Andrew. 1907. The Tinkler-Gypsies. London: Simpkin, Marshall, Hamilton, Kent. [Repr. Darby: Norwood, 1973.]

McCracken-Flesher, Caroline. 2012. The Doctor Dissected: A Cultural Autopsy of the Burke and Hare Murders. Oxford: Oxford University Press.

McEwen, John. 1981. Who Owns Scotland: A Study in Land Ownership. Edinburgh: Polygon.

Munro, Ailie. 1996. The Democratic Music: Folk Music Revival in Scotland. With a chapter on the Folk Revival in Gaelic Song by Morag Macleod. Aberdeen: Scottish Cultural Press.

Nicolaisen, W. F. H. 1985. Rehearsing the Future in the Folktale. New York Folklore 11 (1-4): 231-238.

Niles, John D. 1986. Context and Loss in Scottish Ballad Tradition. Western Folklore 45: 83-106. http:// www.jstor.org/stable/1500038.

Niles, John D. Forthcoming. Webspinner: Reflections, Songs, and Stories of Duncan Williamson, Scottish Traveller. Jackson: University Press of Mississippi.

Ó hAodha, Mícheál. 2002. Exoticising the Gypsies: The Case of Scott Macfie and the Gypsylorists. In Travellers and their Language, eds. John M. Kirk and Dónall P. Ó Baoill, 101-112. Belfast: Cló Ollscoil na Banríona.

Pullar, David, and Ruthie Redden. 2019. Wee Bessie. [n.p.]: HOTT Press.

Robertson, Jeannie. 1962. Oh What did He Feck Ye?: Interview by Hamish Henderson, Tobar an Dualchais. https://www.tobarandualchais.co.uk/track/18105?l=en/.

Robertson, Stanley. 1979. A Song in Cant Warns a Traveller Not to Drink Drugged Tea Given to Him. Interview by Barbara McDermitt, Tobar an Dualchais. http://tobarandualchais.co.uk/en/fullrecord/65216/.

Robertson, Stanley. 1988. Exodus to Alford. Nairn: Balnain.

Robertson, Stanley. 2003. Son David, Text and Context: Lecture, Taught MLitt in Ethnology and Folklore, EI 2003.113. Elphinstone Institute, University of Aberdeen.

Robertson, Stanley. 2005. Scottish Travelling People. In Scottish Life and Society: The Individual and Community: Vol. 9 of A Compendium of Scottish Ethnology. Edinburgh, East Linton: John Donald and Tuckwell, European Ethnological Research Centre, National Museums of Scotland.

Robertson, Stanley. 2006. Rum Scum Scoosh!: Songs and Stories of an Aberdeen Childhood. Aberdeen: Elphinstone Institute, EICD003.

Rosner, Lisa. 2010. The Anatomy Murders: Being the True and Spectacular History of Edinburgh's Notorious Burke and Hare, and of the Man of Science who Abetted them in the Commission of their Most Heinous Crimes. Philadelphia: University of Pennsylvania Press.

Roud, Steve, and Julia Bishop. 2017. English Folk Song. London: Faber and Faber.

Roud, Steve. N.d. The Roud Index. https://www.vwml.org/component/content/article/20-vwml-site/ vwml-help-pages/256-roud-index-guide.

Smith, Jess. 2002. Jessie's Journey: Autobiography of a Traveller Girl. Edinburgh: Mercat Press.

Smith, Jess. 2015. The Way of the Wanderers: The Story of Travellers in Scotland. Edinburgh: Birlinn. 
Sparling, Heather. 2014. Reeling Roosters and Dancing Ducks: Celtic Mouth Music. Sydney: Cape Breton University Press.

Stewart, Elizabeth, and Alison McMorland. 2012. Up Yon Wide and Lonely Glen: Travellers'songs, Stories and Tunes of the Fetterangus Stewarts. Jackson: University Press of Mississippi, Elphinstone Institute.

Stewart, Lucy, Jean Stewart, and Charles Fiddes Reid. 1959. Riddles and Conundrums (and other Titles). Interview by Kenneth S. Goldstein, Tobar an Dualchais. http://www.tobarandualchais.co.uk/en/ searchByTrackId?id=SA1960.138\%.

Stewart, Lucy. 1955. Examples of Cant Words. Interview by Hamish Henderson, Tobar an Dualchais. http:// tobarandualchais.co.uk/en/fullrecord/11576.

Stewart, Sheila. 2002. Cant: A Scottish Traveller's Perspective. In Travellers and their Language, eds. John M Kirk, and Dónall P. Ó Baoill, 188-191. Belfast: Cló Ollscoil na Banríona.

Whyte, Betsy. 1973. Travellers Used Cant Words when People in Authority were About. Interview by Peter R. Cooke and Linda Williamson, Tobar an Dualchais. http://tobarandualchais.co.uk/en/ fullrecord/76578.

Whyte, Betsy. 1979. The Yellow on the Broom: The Early Days of a Traveller Woman. Edinburgh: Chambers.

Whyte, Betsy. 1990. Red Rowans and Wild Honey. Edinburgh: Canongate.

Wightman, Andy. 2015. The Poor Had No Lawyers: Who Owns Scotland and How They Got It. Edinburgh: Birlinn.

Yamasaki, Ryo. From the Uneducated to Intellectuals: A Scottish Traveller Self-Image in Stanley Robertson's Life Writing. PhD dissertation. Kyoto: Ritsumeikan University. [in print].

\section{VEČPLASTNA KOMUNIKACIJA IN FUNKCIJA V ŠKOTSKEM ŽARGONU POPOTNIKOV}

Škotski popotniki poosebljajo značilen pogled na svet, ki pogosto ruši kulturne "norme večinske družbe, zlasti o lastništvu, naselitvi in družbenih strukturah. Škotski žargon popotnikov (angl. Scottisch Traveller Cant), skrivni jezik, ki se uporablja za komunikacijo v majhnih skupinah in družinah, se je v zadnjem stoletju spremenil tako po kontekstu kot po funkciji, vendar je še vedno način, da popotniki nadzorujejo pripovedi o tem, kdo so in kaj želijo biti. Je sredstvo za nadzor in opolnomočenje, ki ga popotniki uporabijo za svoje namene in takrat, ko želijo kaj povedati o sebi.

Cant predstavlja skrivni svet izmenjave informacij, ki je posebej zasnovan tako, da s svojo izjemno kontekstualnostjo in idiolektalno rabo $v$ družinskih skupnostih iz srede popotnikov izključi podeželsko množico (ne-popotniške podeželane) ali včasih celo druge popotnike. $V$ nekaterih primerih njegova raba poudarja nelagodno ločnico med zasebno in družbeno sfero. Toda Cant je tudi ideja, kontekstualni komunikacijski sistem, ki obstaja prav zaradi dejstva, da je živ, v rabi in družbeni funkciji, v konotacijah in ne voznačevanjih ter $v$ besedišcu, ki ga osmišljajo kontekst, gesta, ton glasu in vizualne prvine. 
Do nedavnega je bil v večinski družbi zelo malo opazen, toda kmalu potem, ko so ga »odkrili« raziskovalci in širša javnost, so popotniki (Travellers) začeli brez posredovanja terenskih raziskovalcev svojo zgodbo pripovedovati v objavljenih spominih.

Danes pa vendar še ohranja svojo funkcionalnost, saj se popotniki še naprej ukvarjajo s tistimi zunaj njihove kulture, bodisi pri poslovanju bodisi v javnem okolju, kjer je zaželena zaupnost. Avtor ugotavlja, da je Cant mnogo več kot le jezik. Tako po vsebini kot po strukturi je odsev fluidne obrobnosti velikega dela kulture škotskih popotnikov.

Dr. Thomas A. McKean, University of Aberdeen, The Elphinstone Institute, t.a.mckean@abdn.ac.uk

\section{ACKNOWLEDGEMENTS}

I am grateful to Jess Smith, Eilidh Whiteford, and John D. Niles for their many helpful suggestions as I worked on this paper. Thanks, too, to Linda Williamson for her perspicacious and prompt replies to my queries. Most of all, thank you to all my Traveller friends who have shared so openly of their lives and experience. You are Scotland's royalty. 